\title{
ІНСТИТУЦІЙНИЙ ВИМІР МІЖНАРОДНОГО ФАРМАЦЕВТИЧНОГО САМОРЕГУЛЮВАННЯ
}

\author{
() Б. П. Громовик, О. Б. Панькевич
}

\author{
Львівський національний медичний університет імені Данила Галицького \\ hromovyk@gmail.com,pankevych.lviv@gmail.com
}

\begin{abstract}
Мета роботи. Дослідження інституційних засад саморегулювання фармацевтичної практики (СР ФП) у міжнародному аспекті.

Матеріали і методи. Наукові публікації, що стосуються саморегулювання, офріційні сайти міжнародних фрармацевтичних асоціацій та методологія інституційного виміру.

Результати й обговорення. За даними літературних джерел виявлено історичні передумови становлення СР ФП. Шляхом вивчення інституційних засад СР ФП у міжнародному аспекті встановлено, що майже третина країн, профресійні організації яких є членами Міжнародної фрармацевтичної фредерації (МФФ), представляла Європу. Показано, що трохи більше половини членів ООН через професійні спілки є країнами-членами МФФ, при тому дві третіх європейських країн-членів ООН є членами МФФ. На підставі порівняльного дослідження структури членів МФФ, Фармацевтичної групи Європейського Союзу (ФГЄС) і Європейської асоціації лікарняних фрармацевтів (ЄАЛФ) виявлено, що загалом у трьох досліджуваних асоціаціях присутні 94 фрармацевтичні організації із 39 держав Європи. Поряд з цим у кожній фрармацевтичній асоціації членами є фармацевтичні товариства двох третіх країн і лише чотири профресійні організації $€$ членами водночас трьох фрармацевтичних асоціацій, а саме: Фармацевтична палата Македонії, Хорватське фрармацевтичне товариство, Фармацевтичне товариство Федерації Боснії і Герцеговини та Турецька асоціація фрармацевтів. Дані інституційного виміру показують суттєво низьку участь у діяльності міжнародних асоціацій українських фрармацевтичних товариств. При цьому, за умови приведення статутних документів до вимог конкретної асоціації, відкрито їх доступ не лише до МФФ (Україна член ООН і ВООЗ), а й до ФГЄС (наша держава - член Європейської асоціації вільної торгівлі) та ЄАЛФ (Україна - член Ради Європи).

Висновки. Отримані результати показують різний рівень членства в трьох міжнародних фрармацевтичних асоціаціях (МФФ, ФГЄС і ЄАЛФ) як держав, так й окремих фрармацевтичних товариств, а також надзвичайно низьку участь українських фрармацевтичних товариств у СР ФП у міжнародному аспекті.
\end{abstract}

Ключові слова: самоврядування; Міжнародна фрармацевтична фредерація; Фармацевтична група Європейського Союзу; Європейська асоціація лікарняних фрармацевтів; фрармацевтичні товариства; Всеукраїнська фрармацевтична палата; інституційний вимір.

Вступ. Профресійне саморегулювання (СР) базується на чинному законодавстві, зокрема на ст. 12 і 13 Цивільного Кодексу України, відповідно до яких особа здійснює свої цивільні права вільно, на власний розсуд у межах, наданих їй договором або актами цивільного законодавства [1]. Фармацевтичне СР, як вид професійного СР, має відношення до запобігання недобросовісній, неправильній, неточній або шкідливій фрармацевтичній практиці (ФП), яка може привести до короткострокового прибутку, але зашкодити здоров'ю пацієнта та сприйняттю статусу публічної довіри до цілої профресійної групи - фрармацевтів і провізорів. Саме тому насущними є проблеми, пов'язані 3 профресійним СР та взаємодією його суб'єктів 3 органами державного регулювання ФП. Розвиток ФП зумовлює необхідність постійного вдосконалення механізмів її регулювання. Проте на сьо- годні несприймання органами державної влади повною мірою рівного партнерства із суб'єктами професійного СР і небажання передати частину повноважень щодо СР, у системі організації та надання належних срармацевтичних послуг, призводить до недієвості інституту фрармацевтичного СР.

Теоретичні та практичні аспекти здійснення профресійного СР ФП досліджували у своїх працях ряд українських науковців [2-6]. Незважаючи на наявність цих публікацій, необхідність у подальшому дослідженні державного регулювання і СР ФП актуалізується.

Мета статті полягає у дослідженні інституційних засад СР ФП у міжнародному аспекті.

Матеріали і методи. Матеріалом дослідження були наукові публікації, що стосуються СР та офріційні сайти міжнародних фрармацевтичних асоціацій. У ро-

ISSN 2312-0967. Pharmaceutical review. 2017. № 1 
Організація роботи аптечних підприємств Organization of pharmaceutical structures' work

боті використана методологія інституційного виміру, яка уможливлює розгляд системи СР ФП в ракурсі з'ясування його атрибутивних структурних і фрункціональних властивостей [7].

Результати й обговорення. Необхідно зазначити, що і за кордоном, і в Україні, прообразами організацій фрармацевтичного СР були аптечні гільдії і цехи. Перші суспільні аптеки фрункціонували ще в одинадцятому столітті в Італії і Франції. У 1170 р. в аптекарському статуті м. Арль у Франції (Арльський статут) вперше було закріплено розділення професій лікаря і аптекаря [8]. Король Сицилії, германський король й імператор Священної Римської імперії Фрідріх II в 1224 р. видав декрет, в якому вдруге розділив фрункції лікаря й аптекаря і визначив фрармацію як окрему професію з певними функціями і законодавчо регульованими послугами. В XIII ст. фрармацевти почали створювати свої професійні цехи та гільдії. Дані громадські об'єднання формували певні вимоги освітнього та професійного характеру і контролювали їх дотримання, а також здійснювали захист прав своїх членів [9]. У той же час діяльність подібних організацій контролювалася державними органами. Однак нерідко аптекарі в цих цехах були об'єднані з представниками інших професій: бакалійниками, малярами, гончарями, ювелірами, іноді з лікарями та ін. Такі об'єднання існували в Італії, Франції, Чехії і Польщі. 3 XVI ст. аптекарі починають виходити з об'єднань із представниками інших профресій і створюють лише свої професійні цехи. В Англії цьому посприяла Королівська хартія короля Джеймса (1617р.), в Німеччині - заснування в Нюрнбергзі гільдії «Collegium pharmaceulicum» (1632 р.) [10]. У США перша громадська фрармацевтична організація була заснована в 1821 р. [11].

Професійна організація аптекарів на території України вперше була створена у Львові наприкінці XVI ст. У 1609 р. Львівський аптекарський цех отримав від короля Польщі, Великого князя Литовського і Великого князя Руського Зигмунда III Вази підтвердження прав своєї професійної спільноти. Подібно до інших середньовічних професійних організацій, цех аптекарів об'єднував лише майстрів, тобто аптекарів, які мали право виготовляти і реалізувати ліки і мати аптеку. При цеху зосереджувалося також навчання учнів, а пізніше підмайстрів, тобто помічників аптекарів [12, 13].
Як аптечні цехи поступово почали зникати, їх функції перебирали частково добровільні професійні асоціації і частково уряди.

Нині провідну роль у регулюванні національних вимог і стандартів щодо ФП виконують міжнародні фрармацевтичні організації.

Вагома позиція у професійному СР належить офріційному партнеру ВООЗ - Міжнародній фрармацевтичній федерації (МФФ) - International Pharmaceutical Federation (FIP), що заснована в 1912 р. та представляє світову фрармацію і фрармацевтичну науку (три мільйони фрармацевтів і фрармацевтичних вчених) за допомогою 139 національних організацій, академічних інституційних членів і окремих членів [14]. Основним напрямом діяльності МФФ є задоволення світових потреб і очікувань в галузі охорони здоров'я та сприяння розвитку орармацевтичної професії шляхом просування фрармацевтичної практики і науки для забезпечення пошуку, виробництва, доступності і застосування якісних, ефективних, безпечних, економічно доцільних лікарських засобів. Варто зазначити, що 28 вересня 2015 р. до лав МФФ як постійного організаційного члена було прийнято першу громадську організацію з України - Всеукраїнську фрармацевтичну палату [15]. Доцільно також зауважити, що в офріційний світовий список фрармацевтичних шкіл МФФ внесено лише 6 навчальних закладів України: Львівський національний медичний університет імені Данила Галицького, Івано-Франківський національний медичний університет, Луганський державний медичний університет, Тернопільський державний медичний університет імені І. Я. Горбачевського, Національний фрармацевтичний університет, Запорізький державний медичний університет.

Результати вивчення структури країн, професійні організації яких є членами МФФ, за приналежністю до частин світу показали (табл. 1), що майже третина їх представляла Європу, більше однієї четвертої частини - Афррику, менше однієї четвертої - Азію і лише дві країни Австралію та Океанію. Порівняння кількості країн-членів МФФ і країн-членів ООН виявило, що лише трохи більше половини членів ООН через професійні спілки є країнами-членами МФФ. До того ж, дві третіх європейських країн-членів ООН є членами МФФ. Для Азії цей показник складає понад половину, для Африки - половину, для Америки - дві п'ятих, для Австралії та Океанії - понад однієї десятої частини.

Таблиця 1. Розподіл країн-членів МФФ за частинами світу (станом на 01.02.2017р.)

\begin{tabular}{|l|c|c|c|c|c|}
\hline \multirow{2}{*}{ Частини світу } & \multicolumn{2}{|c|}{ Кількість країн-членів ООН } & \multicolumn{2}{|c|}{ Кількість країн-членів МФФ } & \multirow{2}{*}{ Частка, \% } \\
\cline { 2 - 5 } & абс. & $\%$ & абс. & $\%$ & \\
\hline Європа & 46 & 23,8 & 32 & 32,3 & 69,6 \\
\hline Азія & 44 & 22,8 & 24 & 24,2 & 54,5 \\
\hline Адррика & 54 & 28,0 & 27 & 27,3 & 50,0 \\
\hline Америка & 35 & 38,1 & 14 & 14,1 & 40,0 \\
\hline Австралія та Океанія & 14 & 7,3 & 2 & 2,0 & 14,3 \\
\hline Разом & 193 & 100,0 & 99 & 99,9 & 51,3 \\
\hline
\end{tabular}

ISSN 2312-0967. Фармацевтичний часопис. 2017. № 1 
У подальшому встановлено, що майже половина (44,6 \%) організацій-членів ММФ є 3 понад однієї п'ятої (23,2 \%) країн світу (табл. 2). При цьому з чотирьох країн (Франції, Австралії, США та Японії) членами ММФ є понад десята частина $(13,7$ \%) фрармацевтичних організацій. умовах стаціонару. Це досягається за допомогою наукових досліджень, освіти, практики, а також обміну інорормацією про найкращу ФП і відповідальності 3 іншими орахівцями в галузі охорони здоров'я. Членство в ЄАЛФ відкрито для країн-членів Ради Європи [17]. Водночас ЄАЛФ є членом МФФ.

Таблиця 2. Розподіл організацій-членів МФФ за країнами (станом на 01.02.2017р.)

\begin{tabular}{|c|c|c|c|c|c|c|c|}
\hline \multirow{2}{*}{$\begin{array}{c}\text { № } \\
\text { 3a/n }\end{array}$} & \multirow[t]{2}{*}{ Країна } & \multicolumn{2}{|c|}{$\begin{array}{c}\text { Число організацій- } \\
\text { членів МФФ }\end{array}$} & \multirow{2}{*}{$\begin{array}{c}\text { № } \\
\text { 3a/ח }\end{array}$} & \multirow[t]{2}{*}{ Країна } & \multicolumn{2}{|c|}{$\begin{array}{c}\text { Число організацій- } \\
\text { членів МФФ }\end{array}$} \\
\hline & & абс. & $\%$ & & & абс. & $\%$ \\
\hline 1 & Франція & 7 & 5,0 & 14 & Данія & 2 & 1,4 \\
\hline 2 & Австралія & 4 & 2,9 & 15 & Ірландія & 2 & 1,4 \\
\hline 3 & США & 4 & 2,9 & 16 & Іспанія & 2 & 1,4 \\
\hline 4 & Японія & 4 & 2,9 & 17 & Конго & 2 & 1,4 \\
\hline 5 & Індія & 3 & 2,2 & 18 & Нігерія & 2 & 1,4 \\
\hline 6 & Китай & 3 & 2,2 & 19 & Португалія & 2 & 1,4 \\
\hline 7 & Норвегія & 3 & 2,2 & 20 & Румунія & 2 & 1,4 \\
\hline 8 & Пакистан & 3 & 2,2 & 21 & Сербія + Косово & 2 & 1,4 \\
\hline 9 & Фінляндія & 3 & 2,2 & 22 & Туреччина & 2 & 1,4 \\
\hline 10 & Австрія & 2 & 1,4 & 23 & Швеція & 2 & 1,4 \\
\hline 11 & Бельгія & 2 & 1,4 & & Всього & 62 & 44,6 \\
\hline 12 & Боснія і Герцеговина & 2 & 1,4 & $24-99$ & Інші & 77 & 55,4 \\
\hline 13 & Велика Британія & 2 & 1,4 & & Разом & 139 & 100,0 \\
\hline
\end{tabular}

На завершення нами було вивчено структуру членів двох європейський фрармацевтичних асоціацій порівняно з МФФ, а саме:

1. Фармацевтичної групи Європейського Союзу (ФГЄС) - Pharmaceutical Group of the European Union (PGEU) - міжнародної некомерційної організації та європейської асоціації, що заснована в 1959 р. і представляє фрармацевтичну спільноту щодо законодавчих і політичних ініціатив на рівні $Є С$, які впливають на профресію орармацевта та / або громадську охорону здоров'я. Організація підтримує регулярні контакти 3 Європейською комісією, Європейським Парламентом, Комітетом постійних представників і Економічного та соціального комітету. ІІї членами є національні асоціації та професійні органи співтовариств фрармацевтів із 32 європейських країн, в т. ч. держав-членів ЄС, країн-кандидатів в ЄС і Європейського економічного простору / Європейської асоціації вільної торгівлі. Дійсними членами $€$ асоціації з країн-членів ЄС, а членами-спостерігачами - 3 європейських країн, які не є членами ЄС [16].

2. Європейської асоціації лікарняних фрармацевтів (ЄАЛФ) - European Association of Hospital Pharmacists (EAHР), яка створена 1972 р. та є міжнародною некомерційною організацією і єдиною асоціацією національних організацій, що представляють лікарняних фрармацевтів на європейському і міжнародному рівнях. На сьогодні її членами є фрармацевтичні організації з 35 європейських країн, які об'єднують 19000 лікарняних фрармацевтів. ЄАЛФ представляє і розвиває профресію лікарняного фрармацевта в межах Європи, з тим щоб забезпечити неперервне поліпшення медичної і фрармацевтичної допомоги пацієнтам в
Як видно з даних таблиці 3, загалом у трьох досліджуваних асоціаціях присутні 94 фрармацевтичні організації із 39 держав Європи. До того ж, у кожній фрармацевтичній асоціації членами є фрармацевтичні товариства 26 або 66,7 \% країн, а саме: Австрія, Бельгія, Боснія і Герцеговина, Велика Британія, Данія, Ірландія, Іспанія, Італія, Македонія, Мальта, Нідерланди, Німеччина, Норвегія, Польща, Португалія, Румунія, Сербія, Словенія, Угорщина, Фінляндія, Франція, Хорватія, Чехія, Швеція, Швейцарія і Туреччина. Щодо окремих фрармацевтичних асоціацій, то:

- 6 країн (Болгарія, Естонія, Греція, Латвія, Люксембург, Словаччина), або 15,4\%, не присутні у МФФ;

- 7 держав (Албанія, Ісландія, Латвія, Литва, Російська Федерація, Україна, Чорногорія), або 17,9 \%, немає у ФГЄС;

- 4 країни (Албанія, Кіпр, Російська Федерація, Україна), або 10,3 \%, не наявні у ЄАЛФ.

Необхідно зазначити, що лише 4, або 4,3 \%, профресійних організацій є членами водночас трьох фрармацевтичних асоціацій, а саме: Фармацевтична палата Македонії, Хорватське фрармацевтичне товариство, Фармацевтичне товариство Федерації Боснії і Герцеговини та Турецька асоціація фрармацевтів. Варто виділити участь Франції в досліджуваних асоціаціях, членами яких є 9 різних товариств, проте жодне 3 них не представлено одночасно в усіх асоціаціях.

Воднораз членами двох асоціацій є:

- для МФФ і ФГЄС - 17, або 18,1 \%, професійних організацій з 14, або 35,9 \% країн;

ISSN 2312-0967. Pharmaceutical review. 2017. № 1 
Організація роботи аптечних підприємств

Organization of pharmaceutical structures' work

\begin{tabular}{|c|c|c|c|c|c|c|c|c|c|c|c|c|c|c|c|c|c|c|}
\hline 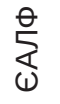 & $0 \cdot \bar{I}$ & & 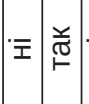 & & $\bar{I} \mid \bar{I}$ & 帝 & 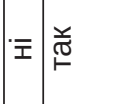 & 艾 & $\overline{\mathbf{I}} \mid \bar{I}$ & $\bar{I}|\bar{I}| \bar{I} \mid \bar{\sigma}$ & 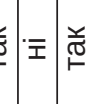 & 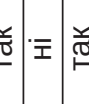 & 突 & 总 & 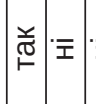 & 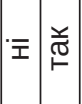 & 亲 & $\bar{I}$ \\
\hline$\frac{\omega}{\theta}$ & เ $\bar{I}$ & & 离 & 站: & 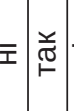 & İ & 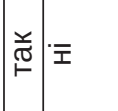 & 芯 & $\overline{\mathbf{I}} \mid \overline{\mathbf{I}}$ & 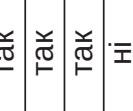 & 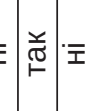 & 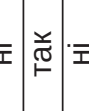 & 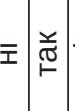 & $\bar{I}$ & 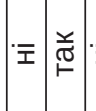 & $\bar{I} \mid \bar{I}$ & : & $\bar{I}$ \\
\hline$\stackrel{\theta}{\Sigma}$ & & & 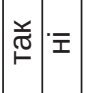 & 帝 & ז & $\bar{I}$ & $\bar{I} \mid \bar{I}$ & 苂 & 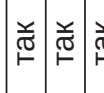 & 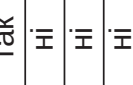 & 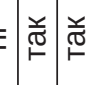 & $\underline{\underline{z}}=\mid \bar{I}: \bar{I}$ & $\bar{I} \mid \bar{I}$. & II & 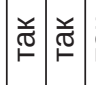 & 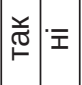 & : & ฮั \\
\hline 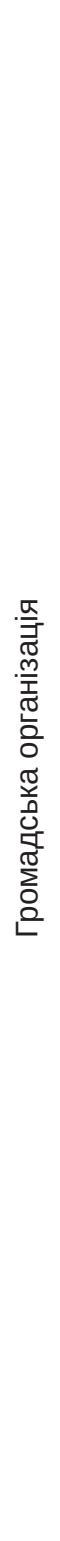 & 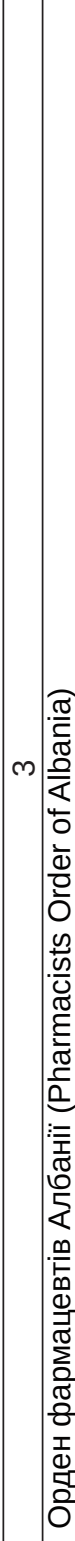 & 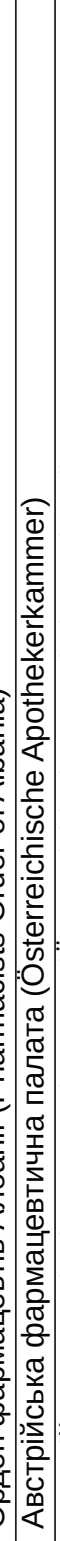 & 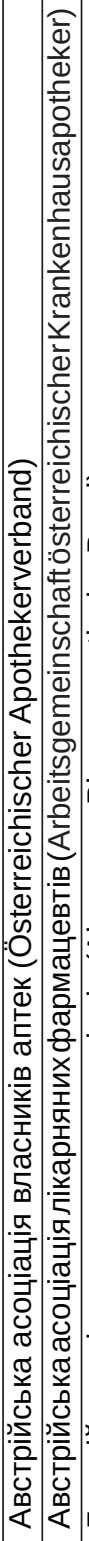 & 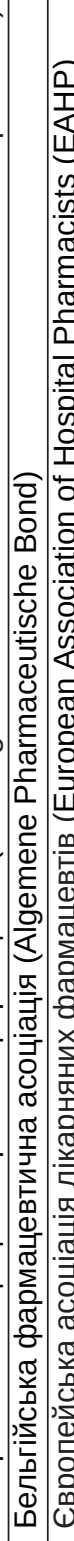 & 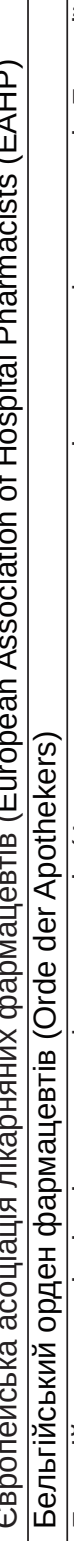 & 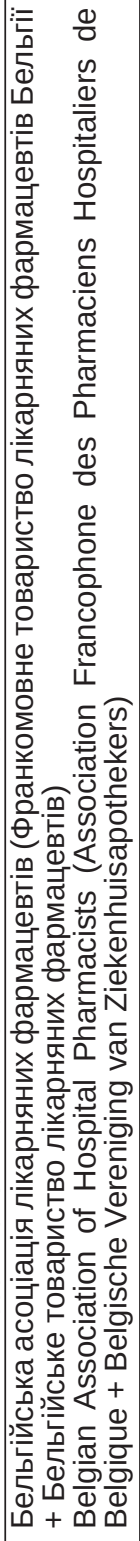 & 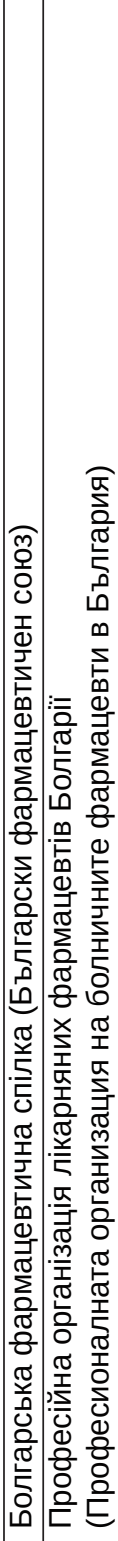 & 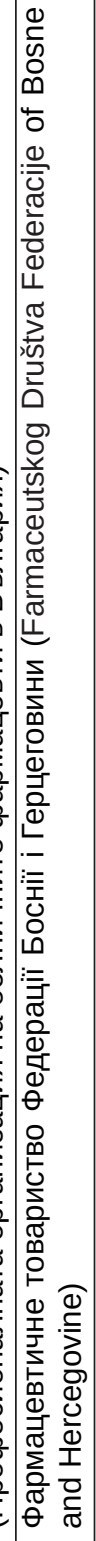 & 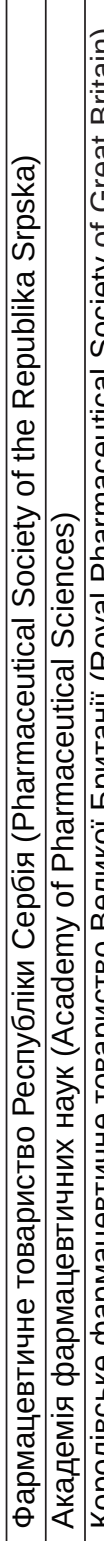 & 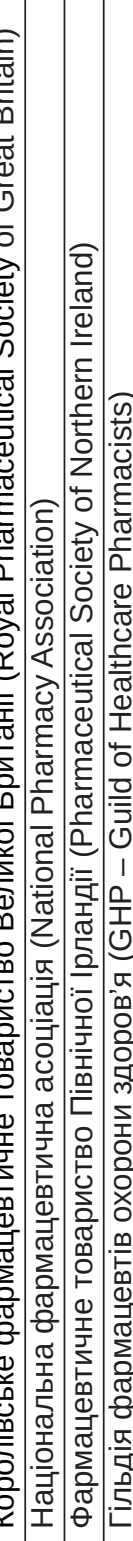 & 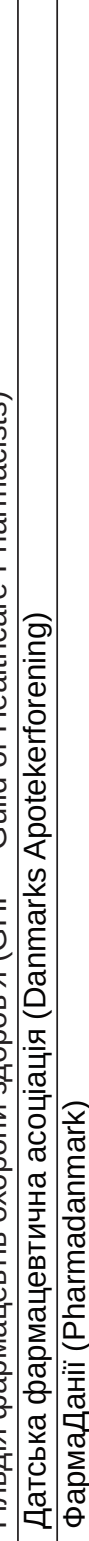 & 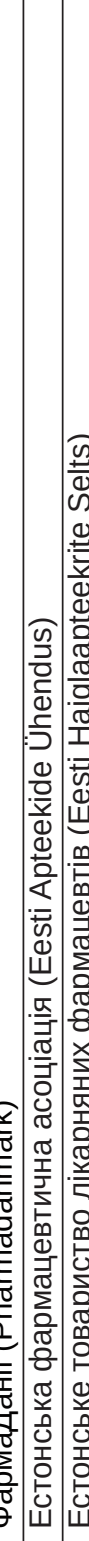 & 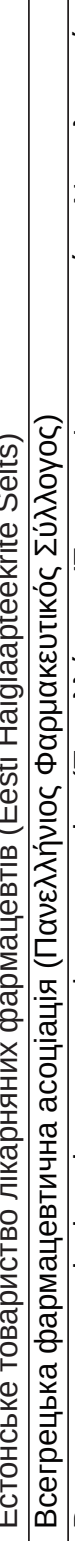 & 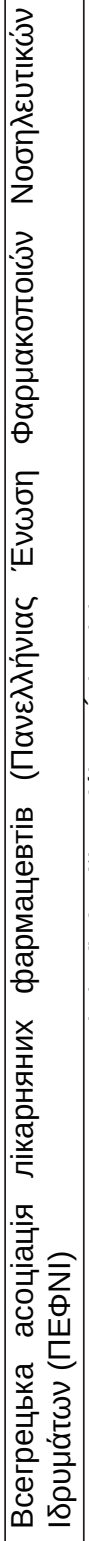 & 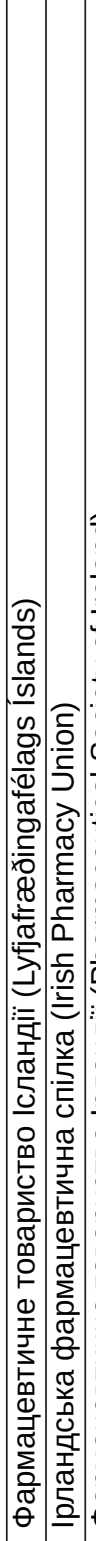 & 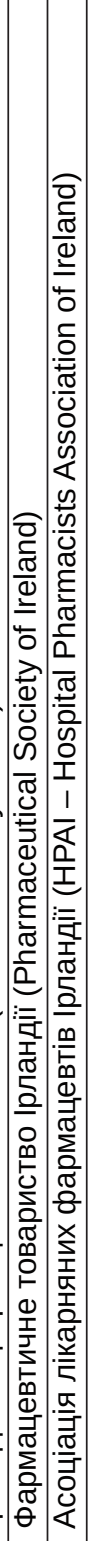 & 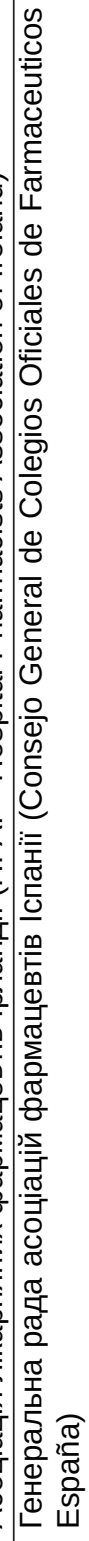 & 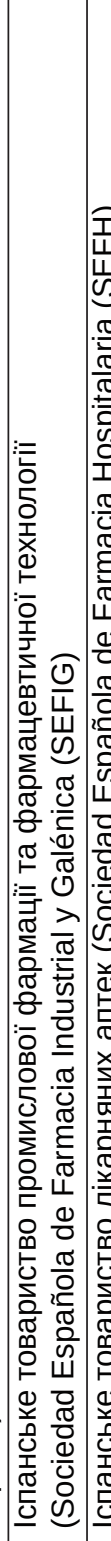 \\
\hline $\begin{array}{l}\frac{\pi}{1} \\
: \frac{\pi}{\pi} \\
\frac{\partial}{x}\end{array}$ & 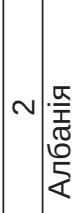 & & & 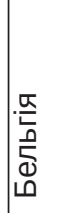 & & & $\mid$ & 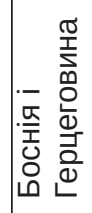 & 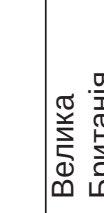 & & 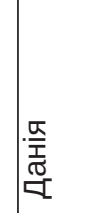 & 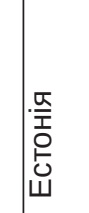 & 言 & & 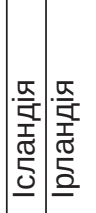 & & 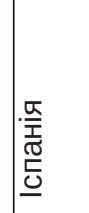 & \\
\hline & -1 & & & $m$ & & & V & ما & 6 & & $\wedge$ & $\infty$ & $\sigma$ & & & & 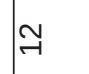 & \\
\hline
\end{tabular}

ISSN 2312-0967. Фармацевтичний часопис. 2017. № 1 
Організація роботи аптечних підприємств

Organization of pharmaceutical structures' work

\begin{tabular}{|c|c|c|c|c|c|c|c|c|c|c|c|c|c|c|c|c|c|c|c|c|c|c|}
\hline 0 & $\mid \bar{I}$ & $\bar{I}$ & 递 & 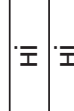 & 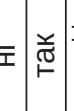 & $\mid$ & 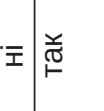 & 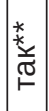 & $\bar{I} \mid \bar{I}$ & 咅 & 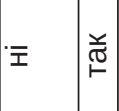 & $\underline{E} \mid \bar{x}$ & 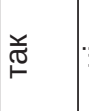 & $\bar{I} \mid \bar{I}$ & \begin{tabular}{|l|l|}
$\bar{I}$ & $\stackrel{\check{\sigma}}{\leftrightarrows}$ \\
\end{tabular} & $\overline{\bar{I}}$ & $\bar{I} \mid \bar{I}$ & 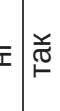 & ๘ૅ & $\bar{I}$ & $\bar{I} \mid \bar{I}$ & 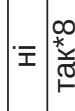 \\
\hline ऽ & $\bar{I}$ & 兽 & İ & & 흔 & & 莣|可 & 茎 & & $\bar{I}$ & $\bar{I}$ & 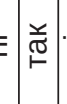 & 포 & & & $\overline{\bar{I}}$ 至 & 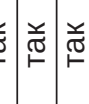 & 든 & $\bar{I}$ & $\bar{I}$ & 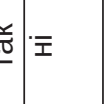 & * \\
\hline$\nabla$ & 覮 & $\bar{I}$ & $\bar{I}$ & 亲 & $\bar{I} \mid \bar{I}$ & $\mid$ & $\overline{\mathbf{I}} \mid \overline{\mathbf{I}}$ & 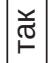 & 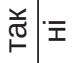 & $\bar{I}$ & 帝 & $=\mid$ & Iㅍ & 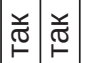 & 产 & 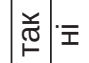 & $=\mid$\begin{tabular}{l|l}
$\stackrel{2}{\sigma}$ \\
$\stackrel{2}{\sigma}$
\end{tabular} & $\overline{\mathbf{I}} \mid \overline{\mathbf{I}}$ & 产 & 养 & $\bar{\Sigma}$ & 㝕|: \\
\hline & 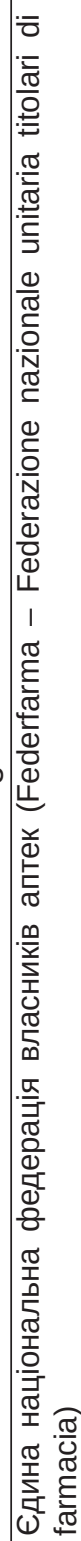 & & 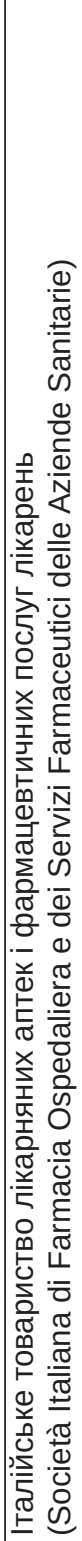 & 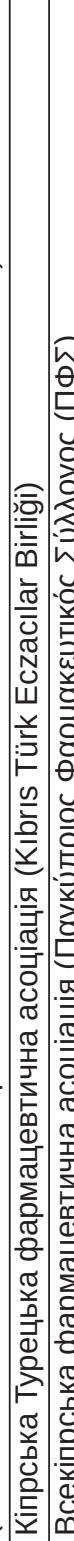 & 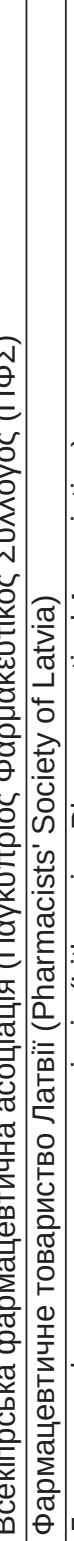 & 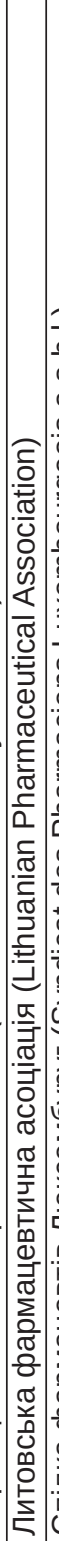 & 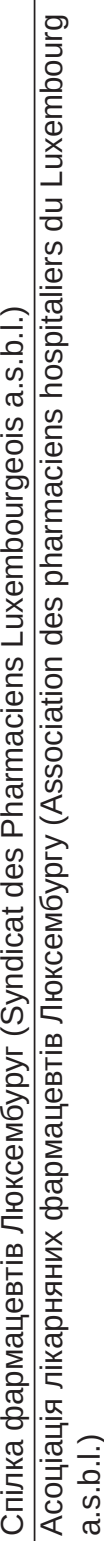 & 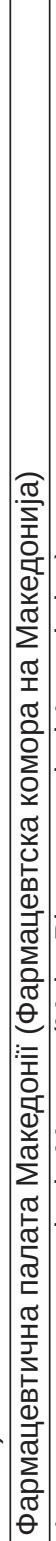 & 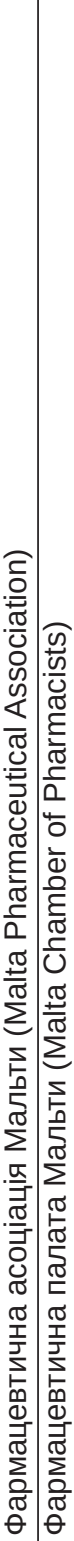 & & 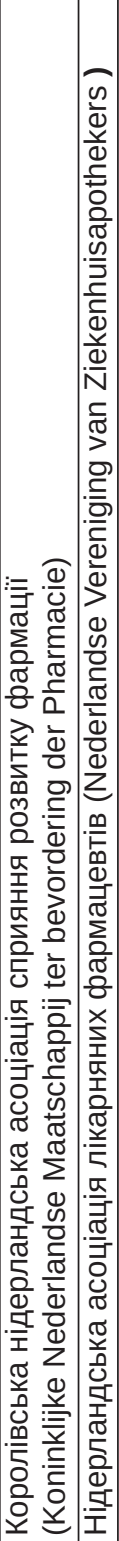 & 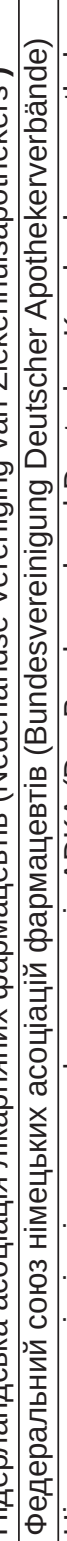 & 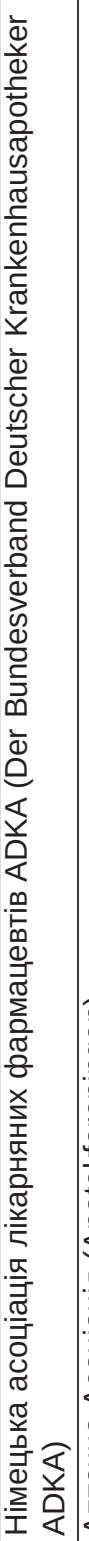 & 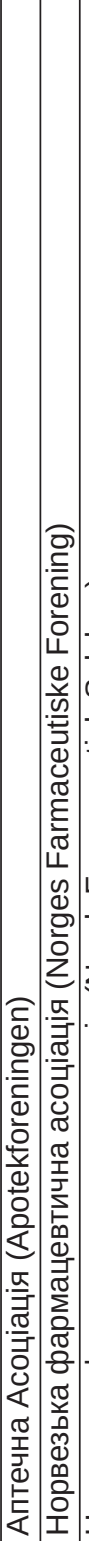 & 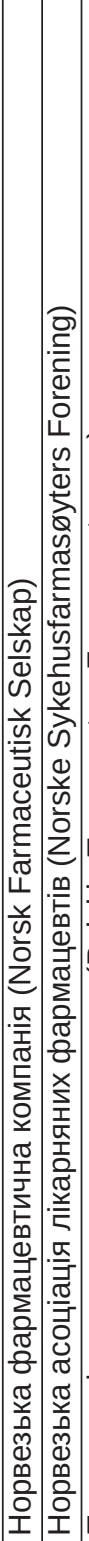 & 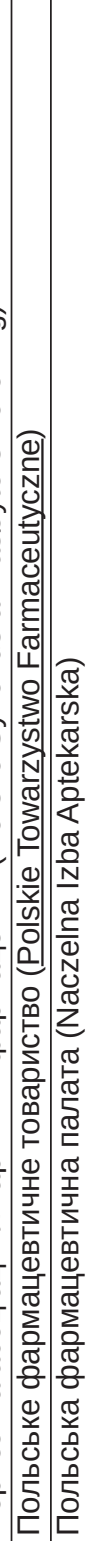 & 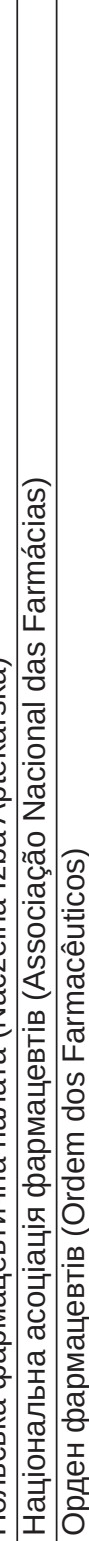 & 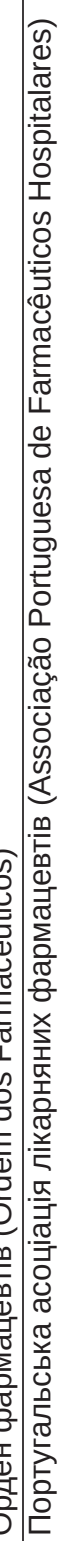 & 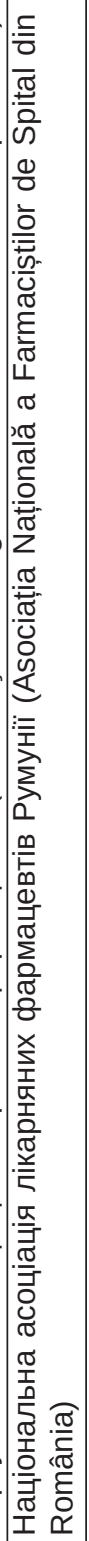 & 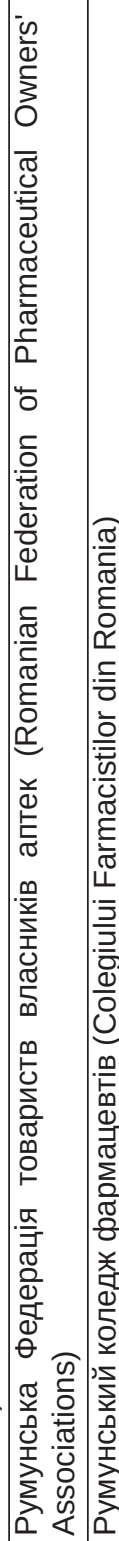 & 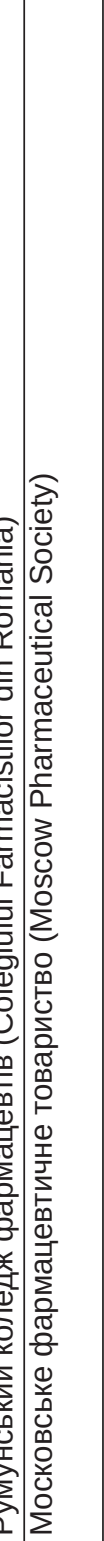 & 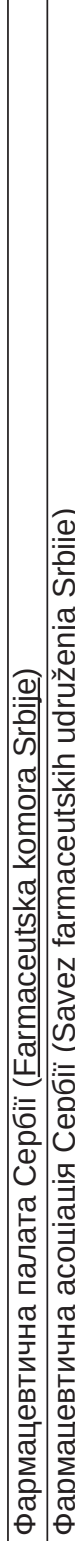 \\
\hline & 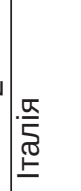 & & & 㕸 & 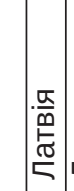 & 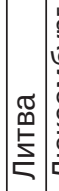 & & & & & 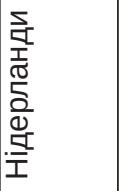 & 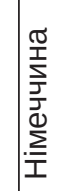 & & 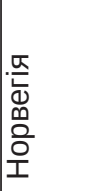 & & 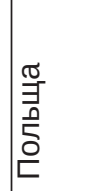 & 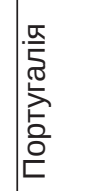 & & 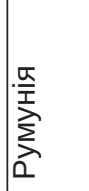 & & 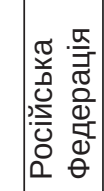 & \\
\hline & & & & & $\mid$ & & & & & & ID & & & & & & N & & & & $\stackrel{\leftrightarrow}{N}$ & \\
\hline
\end{tabular}


Організація роботи аптечних підприємств

Organization of pharmaceutical structures' work

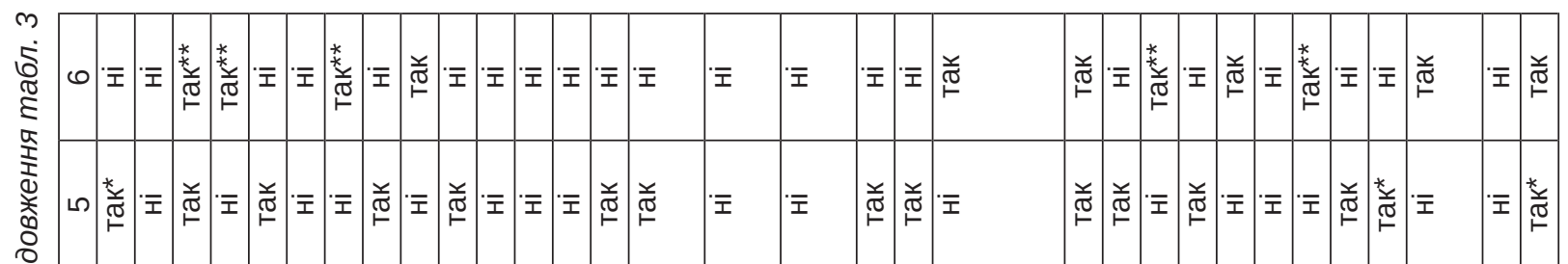

을

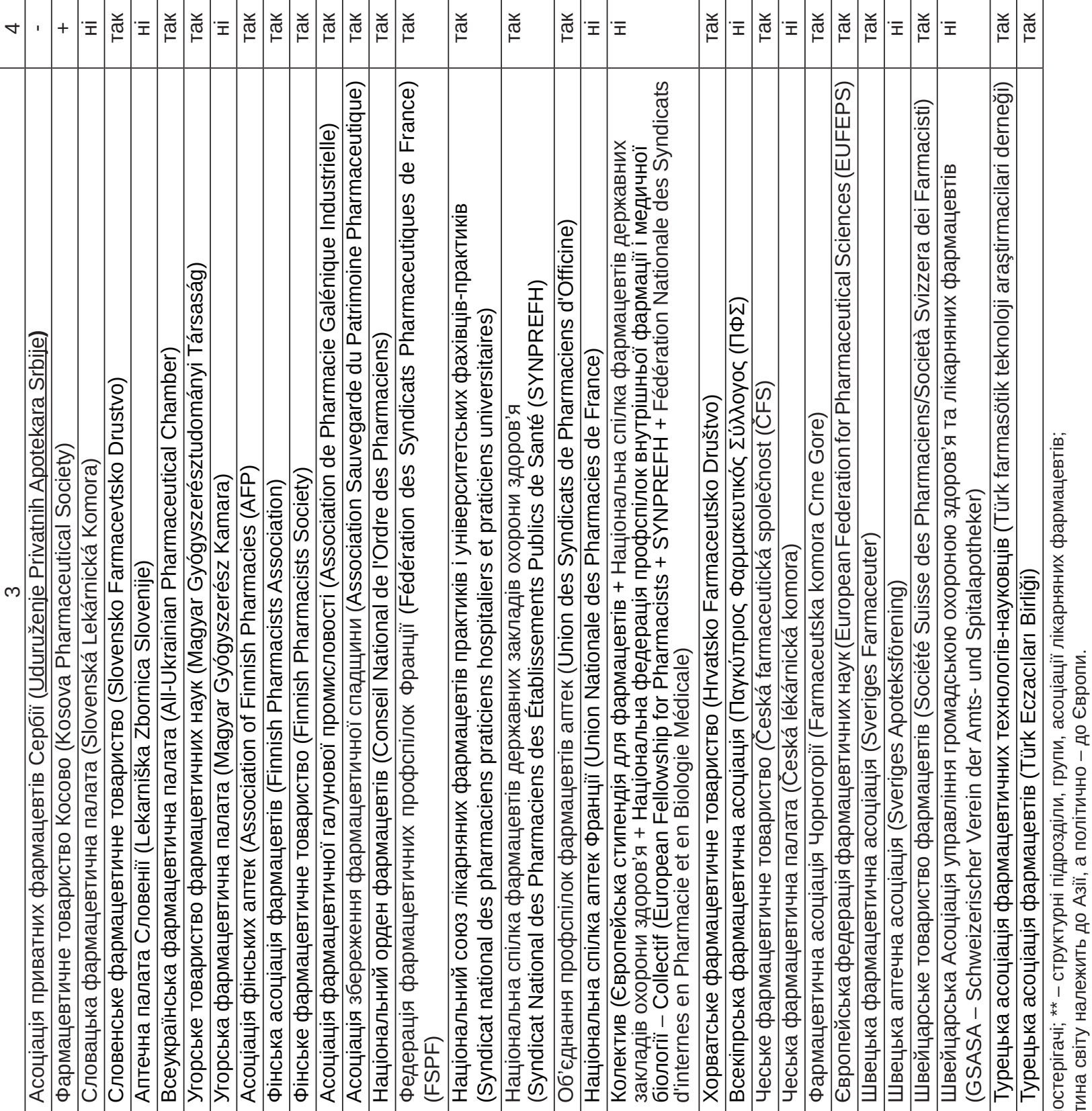

\begin{tabular}{|c|c|c|c|c|c|c|c|c|c|}
\hline$\sim$ & 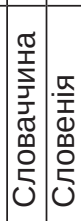 & 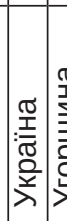 & 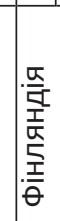 & 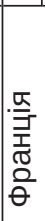 & 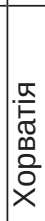 & $\mid \begin{array}{l}\mid \frac{\alpha}{x} \\
\frac{\alpha}{\sigma}\end{array}$ & 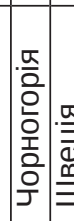 & 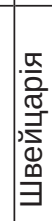 & 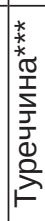 \\
\hline-1 & $\stackrel{\infty}{\sim} \underset{\sim}{\mathbb{N}}$ & প্ল & $\tilde{m}$ & m & ले & 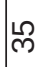 & 必 & | & হ্লি \\
\hline
\end{tabular}

ISSN 2312-0967. Фармацевтичний часопис. 2017. № 1 
Організація роботи аптечних підприємств Organization of pharmaceutical structures' work

- для МФФ і ЄАЛФ - 8 або 8,5 \% товариств 38 або 20,5 \% держав;

- для ФГЄС і ЄАЛФ - три, або 3,2 \%, профресійних спільнот із трьох, або 7,7 \% країн.

Таким чином, для трьох міжнародних фрармацевтичних асоціацій характерний різний рівень членства як держав, так й окремих фармацевтичних товариств, а також надзвичайно низька участь у діяльності цих асоціацій українських фармацевтичних товариств, яких налічується понад 60.
Поряд з цим, за умови приведення статутних документів до вимог конкретної асоціації, відкрито їх доступ не лише до МФФ (Україна - член ООН і ВООЗ), а й до ФГЄС (наша держава - член Європейської асоціації вільної торгівлі) та ЄАЛФ (Україна - член Ради Європи).

Висновки. Отримані результати показують різний рівень членства в трьох міжнародних фрармацевтичних асоціаціях (МФФ, ФГЄС і ЄАЛФ) як держав, так й окремих фрармацевтичних товариств, а також надзвичайно низьку участь українських фрармацевтичних товариств у СР ФП у міжнародному аспекті.

\title{
ИНСТИТУЦИОННОЕ ИЗМЕРЕНИЕ МЕЖДУНАРОДНОГО ФАРМАЦЕВТИЧЕСКОГО САМОРЕГУЛИРОВАНИЯ
}

\author{
Б. П. Громовик, О. Б. Панькевич \\ Львовский национальный медицинский университет имени Данила Галицкого \\ hromovyk@gmail.com, pankevych.lviv@gmail.com
}

Цель работы. Исследование институционных основ саморегулирования фрармацевтической практики (СР ФП) в международном аспекте.

Материалы и методы. Научные публикации по вопросам саморегулирования, официальные сайты международных фрармацевтических ассоциаций и методология институционного измерения.

Результаты и обсуждение. По данным литературных источников выявлено исторические предпосылки становления СР ФП. Путем изучения институционных основ СР ФП в международном аспекте установлено, что почти треть стран, профессиональные организации которых являются членами Международной фармацевтической федерации (МФФ), представляла Европу. Показано, что чуть больше половины членов ООН через профессиональные союзы являются странами-членами МФФ, наряду с этим две трети европейских стран-членов ООН являются членами МФФ. На основании сравнительного исследования структуры членов МФФ, Фармацевтической группы Европейского Союза (ФГЕС) и Европейской ассоциации больничных фармацевтов (ЕАБФ) выявлено, что всего в трех исследуемых ассоциациях присутствуют 94 фрармацевтических организаций из 39 стран Европы. При этом в каждой фармацевтической ассоциации членами являются фрармацевтические общества двух третьих стран и всего четыре профессиональных организаций являются членами одновременно трех фармацевтических ассоциаций, а именно: Фармацевтическая палата Македонии, Хорватское фрармацевтическое общество, Фармацевтическое общество Федерации Боснии и Герцеговины и Турецкая ассоциация фрармацевтов. Данные институционного измерения показывают существенно низкое участие в деятельности международных ассоциаций украинских фрармацевтических обществ. Вместе с тем, при условии приведения уставных документов требованиям конкретной ассоциации, открыт их доступ не только к МФФ (Украина - член ООН и ВОЗ), но и к ФГЕС (наше государство - член Европейской ассоциации свободной торговли) и ЕАБФ (Украина - член Совета Европы).

Выводы. Полученные результаты показывают разный уровень членства в трех международных фрармацевтических ассоциациях (МФФ, ФГЕС и ЕАБФ) как государств, так и отдельных фармацевтических обществ, а также чрезвычайно низкое участие украинских фрармацевтических обществ в СР ФП в международном аспекте.

Ключевые слова: самоуправление; Международная фрармацевтическая федерация; Фармацевтическая группа Европейского Союза; Европейская ассоциация больничных фрармацевтов; фармацевтические общества; Всеукраинская фрармацевтическая палата; институционное измерение.

\section{INSTITUTIONAL DIMENSION OF INTERNATIONAL PHARMACEUTICAL SELF-REGULATION}

\author{
B. P. Hromovyk, O. B. Pankevych
}

Danylo Halytskyi Lviv National Medical University

hromovyk@gmail.com, pankevych.lviv@gmail.com

The aim of the work. Research of self-regulation institutional frameworks for pharmaceutical practice (SR PP) in the international aspect.

ISSN 2312-0967. Pharmaceutical review. 2017. № 1 
Materials and Methods. Scientific publications, related with self-regulation, official websites of international pharmaceutical associations and methodology of institutional dimension.

Results and Discussion. According to the references the historical background of the formation of the SR PP is revealed. By studying institutional frameworks of SR PP in the international aspect, it is founded that almost one third of countries, professional organizations of which are members of the International Pharmaceutical Federation (FIP), represented Europe. It is shown that just over half of the UN members by trade unions are member states of FIP, while two-thirds of European UN member states are members of the FIP. Based on a comparative study of the members' structure of the IPF, Pharmaceutical Group of the European Union (PGEU) and the European association of hospital pharmacists (EAHP). In a total it is found that in three investigated associations are presented 94 pharmaceutical organizations from 39 European countries. Herewith, in each pharmaceutical association the members are pharmaceutical societies of two third countries. Only four professional organizations are members of three pharmaceutical associations simultaneously, namely: Pharmaceutical Chamber of Macedonia, Croatian Pharmaceutical Society, Pharmaceutical Society of Bosnia and Herzegovina Federation and Turkish Pharmacists Association. Data for institutional dimension show significantly low participation activity of Ukrainian pharmaceutical societies' in the international associations. Herein, on condition of statutory documents' bringing to the requirements of a specific association, is opened their access not only to the FIP (Ukraine is a member of UN and WHO), but also yet PGEU (our state is a member of the European Free Trade Association) and EAHP (Ukraine is a member of the Council of Europe).

Conclusions. The obtained results show different levels of membership in the three international pharmaceutical associations (FIP, PGEU and EAHP) as states, and as well as separate pharmaceutical societies, and extremely low Ukrainian pharmaceutical societies' participation in SR PP in the international aspect.

Key words: self-government; International Pharmaceutical Federation; Pharmaceutical Group of the European Union; the European association of hospital pharmacists; pharmaceutical societies; All-Ukrainian Pharmaceutical Chamber; institutional dimension.

\section{Список літератури}

1. Цивільний кодекс України (редакція від 02.11.2016) [Електронний ресурс]. - Режим доступу: http://zakon2. rada.gov.ua/laws/show/435-15.

2. Громовик Б. П. Об'єднання підприємств і громадські організації як суб'єкти саморегулювання національного фрармацевтичного ринку / Б. П. Громовик, Л. М. Унгурян // Укр. мед. альманах. - 2012. - № 5 (15). - С. 86 - 89.

3. Громовик Б. П. До питання формування і функціонування системи фрармацевтичного самоврядування в Україні / Б. П. Громовик, О. Б. Панькевич // «Профресійний менеджмент в сучасних умовах розвитку ринку» : матеріали доповідей $\mathrm{V}$ науково-практичної конореренції 3 міжнародною участю (1 листопада 2016 р.) : збірник. Х. : Монограср. - 2016. - С. 272-274.

4. Назаркіна В. М. Дослідження підходів до впровадження саморегулювання у фрармації / В. М. Назаркіна, В. М. Хоменко, І. В. Сушаріна // Формування національної лікарської політики за умов впровадження медичного страхування: питання освіти, теорії та практики : мат. III Всеукр. наук.-освіт. Internet- конфр., м. Харків, 12 берез. 2015 р. - X., 2015. - C. 168-169.

5. Сушарина І. В. Науково-методичні підходи до оцінки ефективності діяльності громадських організацій у фармації / І. В. Сушарина, А. С. Немченко, В. М. Хоменко // Управління, економіка та забезпечення якості в фрармаціï. - 2016. - № 3 (47). - С. 68-74.

6. Унгурян Л. М. Роль общественных организаций и субъектов хозяйствования в саморегулировании фрармацевтической практики в Украине / Л. М. Унгурян // Вестник Южно-Казахстанской государственной фрармацевтической академии. - 2014. - № 2. - С. 19-25.

7. Бондар О. Інституційний вимір місцевого самоврядування / О. Бондар // Освіта регіону: політологія, психо- логія, комунікації. - 2011. - № 4. - С. 166 - 170.

8. Средневековая медицина и фрармация [Электронный pecypc]. - Режим доступа: http://www.pharmspravka. ru/pharmhistory/farmacija-srednevekovja/srednevekovaya-medicina-i-farmaciya.html.

9. Meriwether M. A. The role of the State in the regulation of pharmacy. Report № 4 / M. A. Meriwether. - Honolulu: University of Hawaii, Legislative Reference Bureau, 1963. - 159 p.

10. Что представляла собой фрармация в Европе в XV-XVII вв.? [Электронный ресурс]. - Режим доступа: http://pharmspravka.ru/farmatsevticheskie-vorosyi-i-otvetyi/chto/chto-predstavlyala-soboy-farmatsiya-v-evrope-v-xv-xvii.html.

11. A History of Pharmacy in Pictures [Online]. - Available at: https://www.pharmacy.wsu.edu/history/A\%2OHistory\% 20of\%20Pharmacy\%20in\%20Pictures.pdf.

12.Грига Н. П. Історія галицького аптекарського товариства та Греміум аптекарів Галичини / Н. П. Грига, М. П. Гуленко // Науково-технічний бюлетень. - 2015. Вип. 16, № 2. - С. 436-438.

13. Głowacki W. Dawne organizacje zawodowe aptekarzy polskich / W. Głowacki // Farmacja Polska. - 1964. № 3-4. - S. 77-79.

14. International Pharmaceutical Federation (FIP) [Online]. - Available at: http://www.fip.org/membership?page=membership_organizations.

15. Снєгірьов П. Україна - у світовій фрармацевтичній сім'ї. ГО «Всеукраїнська фрармацевтична палата» член FIP [Електронний ресурс] / П. Снєгірьов. - Режим доступу: http://www.apteka.ua/article/345865.

16. Pharmaceutical Group of the European Union [Online]. - Available at: http://www.pgeu.eu/en/.

17. European Association of Hospital Pharmacists [Online]. - Available at: http://www.eahp.eu./

ISSN 2312-0967. Фармацевтичний часопис. 2017. № 1 


\section{References}

1. Tsyvilnyi kodeks Ukrainy (redaktsiia vid 02.11.2016): Available from: http://zakon2.rada.gov.ua/laws/show/43515.

2. Hromovyk BP, Unhurian LM. [Association of enterprises and public organizations as subjects of national self-regulation of the pharmaceutical market]. Ukr med almanakh. 2012;5: 86-9. Ukrainian.

3. Hromovyk BP, Pankevych OB. On the question of formation and functioning of the pharmaceutical self-government in Ukraine. [До питання фрормування і фрункціонування системи фрармацевтичного самоврядування в Україні] Kharkiv: National University of Pharmacy; 2016. Ukrainian. 4. Nazarkina VM, Khomenko VM, Susharina IV. Study of approaches to the introduction of self-regulation in pharmacy. [Дослідження підходів до впровадження саморегулювання у фрармації] Kharkiv: National University of Pharmacy; 2015. Ukrainian.

5. Susharyna IV, Nemchenko AS, Khomenko VM. [Scientific-methodical approaches to evaluating the performance of public organizations in pharmacy]. Management, Economics and Quality Assurance in Pharmacy. 2016;3: 68-74. Ukrainian.

6. Unhurian LM. [The role of public organizations and business entities in the self-regulation of pharmacy practice in Ukraine]. Vestnik of the South Kazakhstan state pharmaceutical academy. 2014; 2: 19-25.

7. Bondar O. [The institutional dimension of local government]. Education of the region, political science, psychology, communication. 2011;4: 166-170.
8. Srednevekovaia medytsyna i farmatsyia. Available from: http://www.pharmspravka.ru/pharmhistory/farmacijasrednevekovja/srednevekovaya-medicina-i-farmaciya.html. 9. Meriwether MA The role of the State in the regulation of pharmacy. Report Honolulu: University of Hawaii, Legislative Reference Bureau, 1963;4: 159.

10. Chto predstavliala soboi farmatsyia $\vee$ Evrope $\vee X V$ XVII vv. Available from: http://pharmspravka.ru/farmatsevticheskie-vorosyi-i-otvetyi/chto/chto-predstavlyala-soboy-farmatsiya-v-evrope-v-xv-xvii.html.

11. A History of Pharmacy in Pictures. Available from: https://www.pharmacy.wsu.edu/history/A\%2OHistory\%20 of\%20Pharmacy\%20in\%20Pictures.pdf.

12. Hryha NP, Hulenko MP [History Galician Pharmaceutical companies and pharmacists Hremium Galicia]. Scientific and technical bulletin. 2015;16: 436-438.

13. Głowacki W. Dawne organizacje zawodowe aptekarzy polskich. Farmacja Polska. 1964;3-4: 77-79.

14. International Pharmaceutical Federation (FIP). Available from: http://www.fip.org/membership?page=membership_ organizations.

15. Sniehirov P. Ukraine - in the world pharmaceutical family. NGO "All Ukrainian Pharmaceutical Chamber" - a member of FIP. Available from: http://www.apteka.ua/article/345865.

16. Pharmaceutical Group of the European Union. Available from: http://www.pgeu.eu/en/.

17. European Association of Hospital Pharmacists. Available from: http://www.eahp.eu./ 